\title{
COMPREHENSION OF CREATIVITY IN THE CONTEXT OF THE CORRELATION OF PLATO'S PHILOSOPHY, THEORIES OF FRACTALS AND ARCHETYPES
}

\author{
Anatoliy STOLETOV \\ Department of Social, Economic and Humanitarian Disciplines, Bashkir State Agrarian University, \\ 34 50-letiya Oktyabrya Str., 450001 Ufa, Russia
}

Received 25 August 2020; accepted 2 March 2021

\begin{abstract}
The study examines the creative process using the logical and methodological analysis of Plato's concepts. It presents the modern scientific research related directly or indirectly to his philosophical views (the structural analogy method, the theory of archetypes and fractals and many others). A number of modern studies and concepts, such as the theory of fractals, evolutionary epistemology, the concept of autopoiesis, and others, confirm Plato's views on the structure of the world and creativity. For this reason, the authors define creativity as the activity of a rational and social subject to produce a qualitatively new thing based on universal patterns of the fractal and archetype nature in accordance with the ideal. This activity needs in creativeness which is the state of love as a creative force arising from social interaction as a desire to create and expand space for life, connecting space inside the subject of creativity and outside it, creating a resonance between the creative self and other persons.
\end{abstract}

Keywords: archetype, creative state, creativeness, creativity, eidos, fractal, idea, ideal, Plato.

\section{Introduction}

It is hard to overestimate the influence of the philosophical ideas of Plato, who was the first "systemic" Western philosopher, on the Western philosophy and culture. North Whitehead, a famous British mathematician and philosopher, expressed this meaning in the following words:

"The safest general characterization of the European philosophical tradition is that it consists of a series of footnotes to Plato. I do not mean the systematic scheme of thought, which scholars have doubtfully extracted from his writings. I allude to the wealth of general ideas scattered through them" (1978, p. 39).

The development of society has made the problem of creativity urgent. Creative activity is one of the key aspects of modern civilization, creating its comfort, benefits and the

${ }^{\star}$ Corresponding author. E-mail: aistoletov@gmail.com

Copyright (c) 2022 The Author(s). Published by Vilnius Gediminas Technical University

This is an Open Access article distributed under the terms of the Creative Commons Attribution License (http://creativecommons. org/licenses/by/4.0/), which permits unrestricted use, distribution, and reproduction in any medium, provided the original author and source are credited. 
possibility of a sustainable development. In this regard, the appeal to the ideas of Plato seems to be important for understanding the nature of creativity. Our research shows that many of the ideas of his philosophy have received their confirmation in modern studies. Therefore, the analysis of creativity using the philosophy of Plato can help to reveal the features of the creative process in terms of its fundamental characteristics.

More than two thousand years later, Plato's philosophy still remains the object of researchers (Kraut, 1999) and appears in the many context: linguistic (Joseph, 2006), literary and artistic (Cordingley, 2013; Costelloe, 2012; Gaut, 2007; Pilipović, 2013; Scott, 2011; Tucan, 2013; Voutichtis \& Rehm, 2016), bioethical (Grincevičienė et al., 2015), neuroscience (Carson, 2018; Chávez \& del Carmen Lara, 2000), educational and pedagogical (Çı̆̆ır Dikyol, 2012; George, 2015; Kačerauskas \& Zavadskas, 2015; Karpov, 2015; Shim, 2008; Süzen \& Mamur, 2014; Wang \& Huang, 2018), social and political ones (Grincevičienė et al., 2015; Nicolacopoulos \& Vassilacopoulos, 2017; Pauer, 2003). It is no coincidence that Plato's philosophy arouses such interest even nowadays, since it contains a huge potential for understanding the world, although the perception of these ideas may be rather ambiguous today. It is enough to remember, for example, Popper (2013) or Taleb (2010), who believes that Platonism in the perception of the world - especially the modern one - can pose a serious threat.

Plato repeatedly addressed the theme of creativity in different texts. Various aspects of this theme have become the subject of analysis in the modern works (Carson, 2018; Daniels-McGhee \& Davis, 1994; Kačerauskas, 2008; Kozinets, 2016; Scott, 2011; Shear, 1982; Taliaferro \& Varie, 2018; Tanasić, 2016; Wheeler, 1969).

Despite the abundance of materials on creativity, the concept of Plato is not often involved in the analysis of the ontological foundations of creativity. Many ideas about creativity are contained in a number of Plato's dialogues: the problems of the subject of creativity, its objectives, causes and levels, the ontological foundations, etc. However, these questions are important because they manifest themselves in more specific problems. Thus, the philosophy of Plato is a fertile ground for modern scientific and philosophical developments. Turning to Platonic ideas about the essence of creativity can help us to look at the process of creativity and creative activity in a different way and to understand them more deeply.

We use methods of the logical and methodological analysis of works directly or indirectly related to Plato's concept of structure and functioning of the universe. We consider the theory of synchrony and archetypes by Carl Jung, the concept of fractals, the idea of "ritual repetition" of integral traditionalism, the method of structural analogy as modified forms of Plato's theory about the embodiment of ideas (eidos).

This made it possible to find confirmation of the Platonic understanding of creativity by the data of modern research. Our research shows that scientific data from various fields are largely consistent with Plato's ideas about the structure of the world. This allows us to create a model of creativity based on these data and in accordance with his concepts, as the activity of a rational, social subject for the production of a qualitatively new thing based on universal patterns of a fractal nature in accordance with the ideal, which is present in the form of an archetype at the level of the psyche. 


\section{Plato's concepts in modern science}

The understanding of creativity as a universal attribute of nature is still quite widespread. And this goes back to Plato, who in the dialogue Symposium out of the mouth of a Diotima, claims that creativity is a broad concept, and all creation or the transition of non-being into being is occurs, and the processes of all arts are creative (Plato, 1989).

According to North Whitehead (1967), the neglected evolutionary side of the mechanism can be expressed in the word "creativity" and "organisms can create their own environment". The concept of "organism" does not refer only to biological systems. This term denotes any stable systems, such us atom, molecule, cell, etc. In another lecture on the processes of our universe, he attributes the property of creativity to all existing things. He proclaims creativity as "the universal of universals characterizing ultimate matter of fact" (North Whitehead, 1978, p. 21).

All the above statements characterizing creativity can be reduced to one thesis: creativity is development. The dialectical systems of Georg Wilhelm Friedrich Hegel and Karl Marx reveal the process of development well. It would seem that the laws of dialectics exhaustively explain the process of creativity and can become the basis of the philosophy of creativity. However, that kind of dialectics is rational. This leads to the conclusion about the rationalistic basis of creative processes. Nevertheless, this conclusion contradicts numerous studies of nature, even scientific creativity, which is not limited to logical procedures. For example, Poincaré (1910), reflecting on the nature of mathematical creativity, draws a conclusion about the influence of an infinite number of facts, which, by their infinity, go beyond the capabilities of the human mind. This infinite number of such facts also includes and unconscious phenomena for a human. The French mathematician Hadamard (1954) comes to a similar conclusion by summarizing the experience of scientific creativity of a number of scientists and people of art.

Can we understand creativity for all qualitative changes in the universe as well as North Whitehead understands it? The main argument of the supporters of characterizing creativity as a purely human activity is the statement that the understanding of creativity as an ontological property does not allow it to be distinguished from any processes taking place in the world. The main criterion for creativity in this case is the novelty of the results. In this case, we are faced with a dilemma. On the one hand, even the appearance of a new leaf on a tree is the result of creativity because this leaf has never been in nature before. On the other hand, if we proceed from the principle of the infinity of the universe, it is also inconsistent to assert that such a leaf has never existed in the history of the universe. The definition of creativity as a process that results in the emergence of a qualitatively new object is too broad. The same logical characteristic is inherent in defining this phenomenon as a human activity to create a qualitatively new object. However, for convenience, we suggest starting with an analysis of creativity at the human level since this is the level most studied and understood one.

In this vein, we will try to apply the definition of creativity as a form of a human activity, which is aimed at obtaining a qualitatively new result under the proposed aim. This clarification follows from the need for the presence of reason, which is manifested in the 
purposefulness of person's actions. However, there are different goals. For example, somebody's purpose is to emphasize his originality. For this, he visits his friend in a shoe only on one foot and with a cat's tail instead of a tie. Most likely, the guests will appreciate this "originality" as a form of idiocy and not as creativity.

Another important attribute is general significance. It determines the value of what is created. In their activity, a scientist, an artist, a poet, or a musician try to create things that their community (and, in the ideal case, humanity as a whole) perceives as a value. This concept takes us to the absolute reality, from which we derive samples and goals for our activity. How do we know about this absolute reality?

We believe that Jung describes it in terms of the concept of archetypes. He shows that there are certain structures in the depths of psyche, and the formation of these structures is not connected with the individual experience of a person, his/her education, the social environment where he/she lives or lived. The archetype is a form of expression in an individual of cosmic creative origin connecting him/her with humankind, nature and the entire universe (Jung, 1991). In this context, the concept of archetype is very similar to Platonic "idea", with the help and under the influence of which the potential becomes a real thing and a new reality arises. Jonathan Shear finds a convergence of views in Plato, Jung and Maharishi Mahesh Yogi. He writes that in all three cases the experience (which is beyond all objective qualitative distinctions) is held to be essential not only for full self-knowledge but also for full development of one's mental and creative potential (Shear, 1982, p. 158).

There are several attempts to find the ontological basis of creativity in the biological world, in particular, in the animal wildlife. This is evolutionary epistemology in the works of Popper (1985) and Lorenz (1966). In their opinion, there are ways to deal with the problem, which are formed in the process of long-term biological evolution and are inherited by people genetically.

Under the concept outlined above, the question arises: where did animals get their creativity? The search of their ontological basis returns us once again to the idea of existence of certain generative structures, which Plato called ideas, Aristotle - forms, Jung - archetypes. A number of famous natural scientists have also expressed the idea of their existence. Thus, Werner Heisenberg has repeatedly stressed that the forms we create do not belong to the material world, and they are rooted in the sphere of underlying structures, which Plato called the kingdom of ideas. He believes if we turn to the origins of scientific creativity, we will inevitably come to the conclusion that there are phenomena such as the ideas of Plato (Heisenberg, 2000). Another famous physicist, Carl Friedrich von Weizsäcker, concludes that a person immanently possesses knowledge of the "common". Therefore, it is impossible, for example, to understand the basic ideas of quantum mechanics without understanding the philosophy of Plato (von Weizsäcker, 1980).

A number of cultural studies of authors such as René Guénon and Mircea Eliade, clearly express the idea about the metaphysical nature of the sources of creativity, regardless of time, place and circumstances. Guénon is convinced of the existence of spiritual principles that transform and change secular world. He believes that these spiritual influences must necessarily find appropriate supports in the psychic order at first, and then in the body to interact with our world (Guénon, 2004a, 2004b). According to Eliade (2005), the most visible nature 
of creative forms is exposed in myths, that are associated with the translation of paradigmssamples, and their imitation is a set of actions for which one should take responsibility.

The newly emerging concept of fractals is an unexpected confirmation of Plato's understanding of creativity. Mandelbrot (1977) introduces this concept into science in the mid1970s to describe a phenomenon of similarity, when the geometrical pattern of an entire object is identical to that of its parts and remains constant, regardless of the place, conditions and scale of consideration. The further development of this idea leads to the understanding that fractal structure is found in different, at times even very distant, spheres (Burneko, 2014; Capra \& Luisi, 2016; Colonna, 1995; Downing \& Taylor, 2014; Georgaki \& Tsolakis, 2011; Gerofsky, 2018; Ihsen et al., 1998; Kodama, 2019; Levick \& Kuhn, 2007; Mandelbrot, 1982, 2007; Raye, 2014). Thus, the theory of fractals acquires a philosophical meaning: it claims to explain the deep mechanisms of the world structure, demonstrating the presence of objectively existing invariants of a universal character. The philosophical meaning of the concept of fractals is to point to the identity of the structures of objects belonging to different levels and forms of existence, and that self-similarity is a universal property of nature (Erovenko, 2015).

Developing a similar idea, Talanov (2013) finds some semblance in the structure and functioning of sign systems describing both of the worlds of science and art (V. Talanov \& M. Talanov, 2017). His research in this direction reveals a striking similarity between the structures of some minerals, whose molecular structure was studied by scientists only in the 20th century, and the ornaments of medieval Islamic art. A fragment of the ornament of the mosque, built in 1094 in Egypt, conveys a structural motif of the mineral fluoborite, and architectural Turkish decorations of the 13th century are an exact copy of the crystal structure of some silicates. Talanov (2013) concludes that a person as a subject of creativity, being part of nature and turning to the depths of the unconscious, is able to be intuitively guided in his work by the same principles that are inherent in the very nature. We would like to stress he is a chemist, and there is no mention of Platonic theory of ideas and Jung's doctrine of archetypes in his works.

The research results of Tin Yau Pang and Sergei Maslov are consistent with the same understanding of the nature of fractals. These scholars have found amazing similarities between DNA strands and computer programs. The research shows that the existence of a power law distribution of frequencies of components is a general property of any modular system with a multilayered dependency network and the frequency of a component is positively correlated with its dependency degree given by the total number of upstream components whose operation directly or indirectly depends on the selected component (Pang \& Maslov, 2013).

The idea of the heuristicness of fractals as supra-material and supra-psychical generating bases can be presented in scientific knowledge as the method of structural analogy. Its essence lies in the projection of a certain structure (form) on a new subject area of research. The form rebuilds the elements of the investigated reality and creates a new one. Diana Crane, a sociology of science researcher, concludes that the growth of scientific knowledge is the consequence of "cross-pollination", that is, the transfer of knowledge from one area to another. In her opinion, such a transfer presupposes the existence of some common algorithms for creativity not only in science, but also in culture as a whole (Crane, 1972). Grof (1985) 
also notes that discoveries are the result of transferring data obtained in one area to another for their practical application. This observation is confirmed by the emergence of the concept of electromagnetism; the new quantum-mechanical model of the atom; the "corpuscular" model of the mentality of John Locke, and so on.

Thus, we have reasons to admit the existence of extra-psychic and non-material generating structures that are capable of ordering their elements in a new way and forming another fractal system projecting them on the reality under investigation. This may also explain the phenomenon of synchronicity discovered by Jung. Is this creativity if it occurs outside of human activity?

We believe that a certain kind of human activity is creativity. This statement follows from the fact that one of the important functions of language is the quantitative assessment of reality. A word is a representative of an object, namely, a thing, an event, a property or relationship. The better the language performs this function, the richer and more accurate it can convey the features of an object. Let us consider the word "creativity" from this position. It seems to have emerged primarily in order to denote any kind of human activity: an artist, a poet, a writer, a scientist, and a sculptor. According to the rules of language development, it began to to be explained by adjectives - good/bad artist, famous/unknown scientist, creative/ primitive designer, etc. There are other characteristics of this type of activity: "throes of creation", "joy of creativity", "muses of creativity", etc. We cannot say that the atom experiences "throes of creation", trying to connect with another atom to create a molecule a new kind of reality. Therefore, it makes sense to designate the human way of creation as "creativity" in order to distinguish from a number of situations in which new things appear in nature.

This does not mean at all that we deny the existence of common laws in the processes of emergence of a new one in biological and non-biological world. Some ethological studies show that signs of creative behavior are found in animals and even in birds and reptiles (Kaufman et al., 2011; de Waal, 2014, 2017). Accordingly, the question of the boundary between a part of the world, for which creativity is inherent, and a part, for which it is unusual, is rather complicated.

Thus, we see that modern research in various fields, such as mathematics, physics, biology, psychology, chemistry, social and cultural sciences, confirm Platonic thoughts about the nature of creativity. The fractality of natural, mental and social objects and processes resembles the structure of the world in Plato's philosophy.

\section{Creativity in the light of Plato's ideas}

The definition of creativity as a form of human activity aimed at obtaining a qualitatively new result to achieve the goal needs clarification. The goal should be universal. Plato sought these universal goals in a perfect world of ideas; and the highest of them is the Good. He claims that every soul aspires to the Good and does everything for it; it feels that there is something, but it is difficult for it to understand what it is. Plato believe that it is difficult to define "good in itself". He suggests using the metaphor of the Good as the semblance of the Sun, and if there is no sunlight, it is impossible to see anything, even with eyes (Plato, 2008a). 
Plato's goal of creativity is not an axiological but a metaphysical category. It is the beginning of all beginnings. Living in the world of imperfect objects, Plato investigates the question of existence and essence of the perfection. Based on the properties of the human soul, he gives his interpretation of the ideal state of the future and classifies states, beginning from the best of them - the ideal state, and ends with the worst - tyranny. Using the analysis of the state structure as an example, Plato shows the hierarchy of being with the Good at the apex. There are two types of movement in relation to the Good - involution and evolution. Involution is the movement from the Good to the lower stages of the universe, and evolution is the ascension from the imperfect to the perfect towards the Good. The second path is considered by us as creativity. And it turns out that Plato's vision of creativity comes down to the fact that it is a movement towards the perfection. If we project this concept in social reality, creativity is the activity of a person to recreate perfect samples.

Plato's paradigm of the hierarchy of being also concerns creativity itself. Analyzing different types of art, Plato concludes that art is an "imitation" of the idea, therefore it cannot be the highest form of creativity. Speaking about the existence of "the idea of a bed", translated into a material object, made by a carpenter, Plato notes that a material bed, painted by an artist on a canvas, is an imitation of a thing which in and of itself is secondary to the idea. Therefore, the artist's creation is tertiary in the structure of this world (Plato, 2008a). This idea of art as the lowest form of creativity is also present in the dialogue Timaeus (Plato, 2008b).

Unlike Plato, we do not consider art as the lowest form of creativity. Artistic masterpieces are sometimes able to convey to people the meaning of an object to people more effectively than scientific and philosophical reasoning do. Plotinus reveals the essence of creativity as not a mere imitation of nature or idea, but as an ascension to the principles, bases of things and perfection of objects, thereby bringing them closer to the ideal. He argues that all things imitated by art are themselves images of higher primordial entities. The theme of creativity is not limited only by visible side of things, but goes back to the principles of its nature. The creative personality sometimes adds what is lacking for the perfection of the object:

"The arts do not limit themselves to the imitation of objects which offer themselves to our view, but that they go as far back as the (ideal) reasons from which are derived the nature of objects. Further the arts independently create many things, and to the perfection of the object they add what is lacking, because they possess beauty in themselves" (Plotinus, 2017).

What is the difference between an ideal and an idea understood in its Platonic sense? Plato provides a basis for understanding creativity as a form of movement aimed at achieving the highest form of perfection - an idea that turns into an ideal in its teleological interpretation. This interpretation of the ideal as the supreme goal, being even more distant from the objective reality than the idea, not only in concreto, but also in individuo, is found by us in Immanuel Kant's work. He believes that what we call the ideal Plato refers to as the idea of the divine mind (Nous), a single thing in its pure contemplation, the most perfect type of all the possible essences and the fundamental principle of all copies of the phenomenon (Kant, 2008). Kant gives the same content to the concepts "single object", "single thing" as does Plato: this is an idea, which creates a material object or its image. There is only one idea 
of the bed, but in the process of its implementation by a carpenter or an artist, the beds are getting greater in number.

Another important issue of the topic under study concerns the creative force. The "creating force" is most likely present to varying degrees in every person, and it has repeatedly been the subject of philosophical research. It is mentioned at Plato in the personalized image of Eros. He shows that this desire is present in everything. From this position, creativity as a kind of human activity is the ascension to the Good under the influence of "erotic" energy. In Symposium, this idea becomes the concept of human love as an aspiration to the original integrity - "androgynous": representing the first man as a unified man-woman, which Zeus divided into a man and a woman. Love is the desire of these two halves to unite. Plato postulates love as a universal property of the universe (Plato, 1989). Love in all its forms manifests itself as a creative force.

There is a difference between creativity as a process and creativity as a property (creativeness). The distinction is based on the fact, that creativity as an activity and process needs a prerequisite - a creative state. The creative state presupposes a certain kind of mood, orientation, which determines the nature of creative activity, which (orientation) can be intensive, oraimed at self-development of the subject of creativity, and extensive, or directed at the outside world. The reason for creativity as a creative force lies in social interaction, cooperation between members of the community (Stoletov, 2016).

In the study of Plato's views on poetry, Elizabeth Asmis draws attention to the one feature expressed in Diotima's speech:
"Although Diotima explains this creativity as a semi-divine force, love, striving to attain a transcendental beauty, it is an intensely personal endeavor, strengthened by an interpersonal bond. [...] Like the other 'inventors' and lawgivers, the poet gives voice to his own aspirations as he attempts to transcend his own mortal exist- ence by union with another" (Asmis, 1999, p. 346).

Based on this idea, we see that the semi-divine power of love, which underlies the ability to create, needs an alliance with the other person or social interaction, without which the emergence of a new one is not creativity, but evolution.

The biological research surprisingly confirms both the universality of the creative process associated with cognitive activity and the creative nature of social existence in the universe:

\footnotetext{
"This arises through a novel experience brought forth through reasoning, through the encounter with a stranger, or, more directly, through the expression of a biological interpersonal congruence that lets us see the other person and open up for him room for existence beside us. This act is called love, or, if we prefer a milder expression, the acceptance of the other person beside us in our daily living. This is the biological foundation of social phenomena: without love, without acceptance of others living beside us, there is no social process and, therefore, no humanness" (Maturana \& Varela, 1992).
}

As mentioned above, ethological research reveals both sociality and creativity in animal behavior. Although Chilean scientists base the concept of autopoiesis (about self-generating structure in living systems) on biological research, its implications go far beyond biological processes into social ones. They also confirm Plato's ideas about creativity. Moreover, the 
new scientific paradigm provides the understanding of reason as a process attributable to all living things, albeit to varying degrees (Capra, 1996; Capra \& Luisi, 2016). The question of the boundaries of rationality and sociality requires additional research. But the isotropy of the fractal organization of the universe at different levels may give grounds for expanding the model of creativity beyond the boundaries of human society.

All our reflections on creativity in the context of Plato's ontology, we could summarize in the following definition: creativity is a kind of activity of a reasonable social subject to create a qualitatively new one in accordance with the existing ideal. By the ideal, we mean not only Plato's idea as ideal is comprehended only by the mind. For us, this is a more down-to-earth concept that is a kind of model, according to which a human being builds his actions. It assumes the subject's all-round involvement in creativity, both at the level of reason and at the level of feelings. After all, love as the basis of creativity is the most comprehensive feeling. It is clear that this model varies from person to person saving its pattern. This explains the existence of various scientific schools, directions of painting, forms of prose and poetry.

Although we consider creativity to be a type of human activity, this does not mean a denial of ontogenetic foundations present in a person in the form of unconscious components of his psyche. The archetypal commonality of the psyche determines the fractal nature of creativity, which explains, as in the case of fractals, the presence of both the general and the particular in creative processes. Jungian concept of synchronicity, combined with the theory of fractals, shows that archetypes are psychic fractals similar to natural and mathematical ones. Their similarity, on the one hand, demonstrates the fundamental self-similar nature of the creative process. On the other hand, it confirms the validity of the concept of anamnesis. As in Plato's theory of knowledge, the human soul already possesses truth, so the archetypal level of the psyche contains self-similar forms synchronous with fractals at the level of natural processes, social structures and Plato's eidos at the metaphysical level.

\section{Conclusions}

Brodsky (1995) in his essay "A Cat's Meow" figuratively likens the creative ability to "horizon attachment", and "creativity", for him, is what a vast beach remarks when a grain of sand is swept away by the ocean. The analogy of the creator's involvement in a certain origin - in Plato's terminology "the world of ideas" - is quite indicative. In the context of our research the horizon is a kind of perfect goal, and the ocean is quite comparable to fractal forms.

Therefore, creativeness is the state of love as a creative force arising from social interaction as a desire to create and expand space for life, connecting space inside the subject of creativity and outside it, creating a resonance between the creative self and other people. It presupposes openness to something other than what exists in material level, and improvement towards ideal foundations associated with socially significant values. These values and meanings go back to eidos or perfect models in Plato's philosophy. They are realized through fractals in natural processes. At the level of the psyche, they form a system of archetypes. Creativity is the activity in accordance with this state and factors. 


\section{Acknowledgements}

The author would like to acknowledge the input of Rafael Rakhmatullin, who initiated the study and formed its basic structure.

\section{References}

Asmis, E. (1999). Plato on poetic creativity. In R. Kraut (Ed.), The Cambridge companion to Plato (pp. 338-364). Cambridge University Press. https://doi.org/10.1017/CCOL0521430186.011

Brodsky, J. (1995). On grief and reason: Essays. Farrar, Straus \& Giroux.

Burneko, G. (2014). It's child's play: Contemplative anthropocosmic creativity. World Futures: The Journal of New Paradigm Research, 70(8), 496-514. https://doi.org/10.1080/02604027.2014.988049

Capra, F. (1996). The web of life: A new synthesis of mind and matter. Flamingo.

Capra, F., \& Luisi, P. L. (2016). The systems view of life: A unifying vision. Cambridge University Press.

Carson, Sh. H. (2018). Creativity and psychopathology: A relationship of shared neurocognitive vulnerabilities. In R. E. Jung \& O. Vartanian (Eds.), The Cambridge handbook of the neuroscience of creativity (pp. 136-157). Cambridge University Press. https://doi.org/10.1017/9781316556238.009

Chávez, R. A., \& Carmen Lara, del M. (2000). La creatividad y la psicopatología. Salud Mental, 23(5), $1-9$.

Çığır Dikyol, D. (2012). The effects of Mythos' on Plato's educational approach. Procedia - Social and Behavioral Sciences, 55, 560-567. https://doi.org/10.1016/j.sbspro.2012.09.537

Colonna, J.-F. (1995). Creativity and simplicity. The Visual Computer, 11, 447-452. https://doi.org/10.1007/BF02464334

Cordingley, A. (2013). Beckett's philosophical imagination: Democritus versus Pythagoras and Plato in comment C'est/How It Is. Comparative Literature, 65(4), 383-407. https://doi.org/10.1215/00104124-2376606

Costelloe, T. M. (2012). Imagination and internal sense: The sublime in Shaftesbury, Reid, Addison, and Reynolds. In T. M. Costelloe (Ed.), The Sublime: From antiquity to the present (pp. 50-63). Cambridge University Press. https://doi.org/10.1017/CBO9780511978920.006

Crane, D. (1972). Invisible colleges: Diffusion of knowledge in scientific communities. University of Chicago Press.

Daniels-McGhee, S., \& Davis, G. A. (1994). The imagery-creativity connection. Journal of Creative Behavior, 28(3), 151-176. https://doi.org/10.1002/j.2162-6057.1994.tb01189.x

Downing, R., \& Taylor, R. (2014). The fractal clock: Using chaos to bridge the art-science divide. Nonlinear Dynamics, Psychology, and Life Sciences, 18(1), 109-122.

Eliade, M. (2005). The myth of the eternal return. Princeton University Press.

Erovenko, V. A. (2015). Koncepcija fraktala Mandel'brota s matematicheskoj i filosofskoj tochek zrenija. Matematicheskie struktury i modelirovanie, 4(36), 29-39.

Gaut, B. (2007). Art, emotion and ethics. Oxford University Press. https://doi.org/10.1093/acprof:oso/9780199263219.001.0001

Georgaki, A., \& Tsolakis, Ch. (2011). Fractal based curves in musical creativity: A critical annotation. In Ch. H. Skiadas, I. Dimotikalis \& Ch. Skiadas (Eds.), Chaos theory: Modeling, simulation and applications. Selected Papers from the 3rd Chaotic Modeling and Simulation International Conference (pp. 167-174). World Scientific Publishing Co. Pte. Ltd. https://doi.org/10.1142/9789814350341_0019

George, L. (2015). Socrates on teaching: Looking back to move education forward. Procedia - Social and Behavioral Sciences, 174, 3970-3974. https://doi.org/10.1016/j.sbspro.2015.01.1142 
Gerofsky, S. (Ed.). (2018). Contemporary environmental and mathematics education modelling using new geometric approaches: Geometries of liberation. Palgrave Macmillan. https://doi.org/10.1007/978-3-319-72523-9

Grincevičiene, V., Valatka, V., Grincevičius, J., \& Grincevičienė, Š. (2015). Ethical aspects of pharmacogenetics: A need for creativity. Filosofija. Sociologija, 26(3), 230-238.

Grof, S. (1985). SUNY Series in transpersonal and humanistic psychology. Beyond the brain: Birth, death and transcendence in psychotherapy. R. D. Mann \& J. B. Mann (Eds.). State University of New York Press.

Guénon, R. (2004a). Collected works of René Guénon. The esoterism of Dante. J. R. Wetmore (Series Ed.). Sophia Perennis.

Guénon, R. (2004b). Collected works of René Guénon. The reign of quantity and the signs of the times. J. R. Wetmore (Series Ed.). Sophia Perennis.

Hadamard, J. (1954). An essay on the psychology of invention in the mathematical field. Dover Publications, Inc.

Heisenberg, W. (2000). Physics and philosophy: The revolution in modern science. Penguin Classics.

Ihsen, S., Isenhardt, I., \& Steinhagen De Sanchez, U. (1998). Creativity, complexity and self-similarity: The vision of the fractal university. European Journal of Engineering Education, 23(1), 13-22. https://doi.org/10.1080/0304379980230103

Joseph, J. E. (2006). Plato’s Cratylus and its legacy. In K. Brown (Ed.-in-Chief). Encyclopedia of language and linguistics, Vol. 1 (pp. 636-638). Elsevier. https://doi.org/10.1016/B0-08-044854-2/01344-4

Jung, C. G. (1991). The archetypes and the collective unconscious. Routledge. https://doi.org/10.1515/9780691229782-023

Kačerauskas, T. (2008). Kūnas gyvenamajame pasaulyje. Problemos, 73, 72-82. https://doi.org/10.15388/Problemos.2008.0.2017

Kačerauskas, T., \& Zavadskas, E. K. (2015). Creative ecology in academic environment. Filosofija. Sociologija, 26(3), 239-248.

Kant, I. (2008). Critique of pure reason. Penguin Classics. https://doi.org/10.1007/978-1-137-10016-0

Karpov, A. (2015). The ancient Episteme of activity as ontological horizon of modern education development. Procedia - Social and Behavioral Sciences, 214, 448-456. https://doi.org/10.1016/j.sbspro.2015.11.720

Kaufman, A. B., Butt, A. E., Kaufman, J. C., \& Colbert-White, E. N. (2011). Towards a neurobiology of creativity in nonhuman animals. Journal of Comparative Psychology, 125(3), 255-272. https://doi.org/10.1037/a0023147

Kodama, M. (2019). Business innovation through holistic leadership-developing organizational adaptability. Systems Research and Behavioral Science, 36(4), 365-394. https://doi.org/10.1002/sres.2551

Kozinets, R. (2016). Flow my bits, the professor screened: Netnography, academic micro-celebrity, and personal branding. In M. Cabrera Méndez \& N. Lloret Romero (Eds.), Digital tools for academic branding and self-promotion (pp. 53-66). IGI Global. https://doi.org/10.4018/978-1-5225-0917-2.ch004

Kraut, R. (Ed.). (1999). The Cambridge companion to Plato. Cambridge University Press.

Levick, D., \& Kuhn, L. (2007). Fractality, organizational management, and creative change. World Futures: The Journal of New Paradigm Research, 63(3-4), 265-274.

https://doi.org/10.1080/02604020601174885

Lorenz, K. (1966). On aggression. A Harvest Book.

Mandelbrot, B. B. (1977). Fractals: Form, chance and dimension. W. H. Freeman \& Company.

Mandelbrot, B. B. (2007). Scalebound or scaling shapes: A useful distinction in the visual arts and in the natural sciences. Leonardo, 14, 45-47. https://doi.org/10.2307/1574481 
Mandelbrot, B. B. (1982). The fractal geometry of nature. W. H. Freeman \& Company.

Maturana, H. R., \& Varela, F. J. (1992). The tree of knowledge: The biological roots of human understanding. Shambhala Publications, Inc.

Nicolacopoulos, T., \& Vassilacopoulos, G. (2017). Cave dwellers or labyrinth diggers? Castoriadis and Plato on philosophy and politics. Critical Horizons, 18(2), 119-135. https://doi.org/10.1080/14409917.2017.1293884

North Whitehead, A. (1978). Process and reality: An essay in cosmology. Corrected edition. D. R. Griffin \& D. W. Sherburne (Eds.). The Free Press.

North Whitehead, A. (1967). Science and the modern world. The Free Press.

Pang, T. Y., \& Maslov, S. (2013). Universal distribution of component frequencies in biological and technological systems. Proceedings of the National Academy of Sciences, 110(15), 6235-6239. https://doi.org/10.1073/pnas.1217795110

Pauer, J. (2003). Je ešte možný spoločný svet? Alebo o jednote v mnohosti a o spoločnom základe v potencii. II. Čast: Komplexná doména potencie. Filozofia, 58(3), 188-198.

Pilipović, J. (2013). Ad sidera: Tree-Space symbolism in Plato's Phaedrus and Vergil's Eclogues. Acta Antiqua Academiae Scientiarum Hungaricae, 53(2-3), 221-244.

https://doi.org/10.1556/AAnt.53.2013.2-3.6

Plato. (1989). Symposium. Hackett Publishing Company.

Plato. (2008a). The Republic (pp. 138-157). Digireads.com Publishing.

Plato. (2008b). Timaeus. Book Jungle.

Plotinus. (2017). The Enneads of Plotinus with philosophical commentaries. Ennead V.8: On Intelligible Beauty. J. M. Dillon \& A. Smith (Eds.). Parmenides Publishing.

Poincaré, H. (1910). Mathematical creation. The Monist, 20(3), 321-335. https://doi.org/10.5840/monist19102037

Popper, K. (1985). Evolutionary epistemology. In G. Tarozzi \& A. van der Merwe (Eds.), Fundamental theories of physics: Vol. 10. Open questions in quantum physics (pp. 395-413). Springer. https://doi.org/10.1007/978-94-009-5245-4_27

Popper, K. (2013). The open society and its enemies. Princeton University Press. https://doi.org/10.1515/9781400846672

Raye, J. (2014). Fractal organisation theory. Journal of Organisational Transformation and Social Change, 11(1), 50-68. https://doi.org/10.1179/1477963313Z.00000000025

Scott, D. (2011). Plato: Poetry and creativity. In P. Destrée \& F.-G. Herrmann (Eds.). Mnemosyne, Supplementa: Vol. 328. Plato and the poets (pp. 131-154). Brill. https://doi.org/10.1163/ej.9789004201293.i-434.29

Shear, J. (1982). The universal structures and dynamics of creativity: Maharishi, Plato, Jung and various creative geniuses on the creative process. Journal of Creative Behavior, 16(3), 155-175. https://doi.org/10.1002/j.2162-6057.1982.tb00331.x

Shim, S. H. (2008). A philosophical investigation of the role of teachers: A synthesis of Plato, Confucius, Buber, and Freire. Teaching and Teacher Education, 24(3), 515-535. https://doi.org/10.1016/j.tate.2007.09.014

Stoletov, A. (2016). Social creativity and phenomenon of success in postindustrial society. Creativity Studies, 9(2), 141-150. https://doi.org/10.3846/23450479.2016.1223765

Süzen, H. N., \& Mamur, N. (2014). Reflection of "Philosophy" on art and philosophy of art. Procedia Social and Behavioral Sciences, 122, 261-265. https://doi.org/10.1016/j.sbspro.2014.01.1339

Talanov, V. M. (2013). Vozmozhen li universal'nyj metajazyk kul'tury? Yuzhno-Rossijskij gosudarstvenny'j politexnicheskij universitet im. M. I. Platova. 
Talanov, V., \& Talanov, M. (2017). Structural similarity of sign systems in culture and science. Acta Crystallographica, Section A 70(C1002). https://doi.org/10.1107/S2053273317085722

Taleb, N. N. (2010). The Black Swan: The impact of highly improbable. Random House Publishing Group.

Taliaferro, Ch., \& Varie, M. (2018). The active and passive life of creativity: An essay in a platonic key. In B. Gaut \& M. Kieran (Eds.), Creativity and philosophy (pp. 141-150). Routledge. https://doi.org/10.4324/9781351199797-9

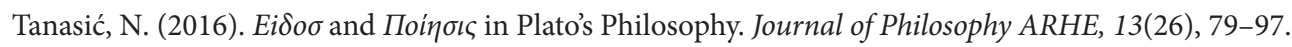

Tucan, D. (2013). The Quarrel between poetry and philosophy: Plato - A sceptical view on "Poetry". Procedia - Social and Behavioral Sciences, 71, 168-175. https://doi.org/10.1016/j.sbspro.2013.01.023

Voutichtis, Ch., \& Rehm, J. A. (2016). No place for urban art. Street Art and Urban Creativity, 2(2), 45-47.

Waal, de F. (2017). Are we smart enough to know how smart animals are? W. W. Norton \& Company.

Waal, de F. (2014). The Bonobo and the Atheist: In search of humanism among the primates. W. W. Norton \& Company.

Wang, T. J., \& Huang, K. H. (2018). Pedagogy, philosophy, and the question of creativity. Teaching in Higher Education, 23(2), 261-273. https://doi.org/10.1080/13562517.2017.1379479

Weizsäcker, von C. F. (1980). The unity of nature. Farrar Straus Giroux.

Wheeler, A. M. (1969). Creativity in Plato's States. Educational Theory, 19(3), 249-255. https://doi.org/10.1111/j.1741-5446.1969.tb00389.x 